\title{
Article \\ Enhanced Hydrocarbons Biodegradation at Deep-Sea Hydrostatic Pressure with Microbial Electrochemical Snorkels
}

\author{
Federico Aulenta ${ }^{1, *(1)}$, Enza Palma ${ }^{1}$, Ugo Marzocchi ${ }^{2,3}{ }^{(1)}$, Carolina Cruz Viggi ${ }^{1}$, Simona Rossetti ${ }^{1}$ and \\ Alberto Scoma $4,5, *$ (D) \\ 1 Water Research Institute (IRSA), National Research Council (CNR), 00015 Monterotondo, Italy; \\ palma@irsa.cnr.it (E.P.); cruzviggi@irsa.cnr.it (C.C.V.); rossetti@irsa.cnr.it (S.R.) \\ 2 Center for Electromicrobiology, Section for Microbiology, Department of Bioscience, Aarhus University, \\ 8000 Aarhus, Denmark; ugomar@bio.au.dk \\ 3 Center for Water Technology (WATEC), Department of Bioscience, Aarhus University, 8000 Aarhus, Denmark \\ 4 Section of Microbiology, Department of Biology, Aarhus University, 8000 Aarhus, Denmark \\ 5 Engineered Microbial Systems (EMS) Lab, Department of Biological and Chemical Engineering (BCE), \\ Aarhus University, 82000 Aarhus, Denmark \\ * Correspondence: aulenta@irsa.cnr.it (F.A.); as@bce.au.dk (A.S.)
}

Citation: Aulenta, F.; Palma, E.; Marzocchi, U.; Cruz Viggi, C.;

Rossetti, S.; Scoma, A. Enhanced Hydrocarbons Biodegradation at Deep-Sea Hydrostatic Pressure with Microbial Electrochemical Snorkels Catalysts 2021, 11, 263. https:// doi.org/10.3390/catal11020263

Academic Editors: Baiyu Zhang and Bo Liu

Received: 26 January 2021

Accepted: 11 February 2021

Published: 16 February 2021

Publisher's Note: MDPI stays neutral with regard to jurisdictional claims in published maps and institutional affiliations.

Copyright: (C) 2021 by the authors. Licensee MDPI, Basel, Switzerland. This article is an open access article distributed under the terms and conditions of the Creative Commons Attribution (CC BY) license (https:/ / creativecommons.org/licenses/by/ $4.0 /)$
Abstract: In anaerobic sediments, microbial degradation of petroleum hydrocarbons is limited by the rapid depletion of electron acceptors (e.g., ferric oxide, sulfate) and accumulation of toxic metabolites (e.g., sulfide, following sulfate reduction). Deep-sea sediments are increasingly impacted by oil contamination, and the elevated hydrostatic pressure (HP) they are subjected to represents an additional limitation for microbial metabolism. While the use of electrodes to support electrobioremediation in oil-contaminated sediments has been described, there is no evidence on their applicability for deep-sea sediments. Here, we tested a passive bioelectrochemical system named "oil-spill snorkel" with two crude oils carrying different alkane contents (4 vs. 15\%), at increased or ambient HP (10 vs. $0.1 \mathrm{MPa}$ ). Snorkels enhanced alkanes biodegradation at both 10 and $0.1 \mathrm{MPa}$ within only seven weeks, as compared to nonconductive glass controls. Microprofiles in anaerobic, contaminated sediments indicated that snorkels kept sulfide concentration to low titers. Bulk-sediment analysis confirmed that sulfide oxidation by snorkels largely regenerated sulfate. Hence, the sole application of snorkels could eliminate a toxicity factor and replenish a spent electron acceptor at increased HP. Both aspects are crucial for petroleum decontamination of the deep sea, a remote environment featured by low metabolic activity.

Keywords: crude oil; hydrostatic pressure; deep sea; alkanes; sulfide; sulfate

\section{Introduction}

Crude oil accidentally released into marine ecosystems results in persisting contamination, particularly in anaerobic sediments. Under anaerobic conditions, some microorganisms can still oxidize petroleum hydrocarbons, provided suitable terminal electron acceptors such as ferric oxide (Fe[III]) or sulfate $\left(\mathrm{SO}_{4}{ }^{2-}\right)$ are present [1]. Electron acceptor availability often represents the limiting factor for microbial metabolism [2]. High carbon loads typical of oil-spill events may cause the rapid depletion of electron acceptors supporting biodegradation processes, resulting in the long-term persistence of the spilled hydrocarbons in sediments. Besides, the accumulation of sulfide $\left(\mathrm{H}_{2} \mathrm{~S}\right)$, originating from $\mathrm{SO}_{4}{ }^{2-}$ reduction, can have toxic effects and immobilize essential trace elements $[3,4]$.

Electrodes applied in contaminated sediments can act as a virtually nonexhaustible electron acceptor, thereby overcoming this limitation in bioremediation processes. In such a bioelectrochemical system (BES), microorganisms can oxidize organic pollutants (and the resulting metabolic intermediates) while transferring electrons to an anode [5], as demonstrated for single aromatic hydrocarbons, e.g., benzene [6-8], phenols [9-11], toluene [12] and naphthalene [6,13], but also crude oil [14-16]. 
Petroleum contamination in deep-sea environments is an emerging threat. Crude oil spills occurring on surface waters may reach seafloors exposed to increased hydrostatic pressure (HP) in numerous ways, e.g., dissolution, emulsification and diffusion in the water column; through injection of chemical dispersants, which also enhances the risk of direct contact of underwater oil plumes with continental slopes; formation and sinking of heavier particles (tar) or marine snow; and in situ oil burning [17]. The spill may originate at depth, as in deep exploration and production platforms [18], accidents at deep-sea wells (e.g., the Deepwater Horizon disaster [19]) or oil seepage from pipelines [18] and sunken shipwrecks $[20,21]$. Microbial-induced corrosion in these shipwrecks can be enhanced by exposure to later oil spills [22], representing an additional risk for the deep sea. The study of deep seafloor decontamination is hampered by their remote location. The use of laboratory-scale high pressure reactors simulating deep-sea environments is an emerging tool in bioremediation studies, which can facilitate testing and upscaling of future technologies.

Here, the electrobioremediation capacity of a passive BES named "oil-spill snorkel" was tested with two crude oils at either ambient or increased HP (i.e., $10 \mathrm{MPa}$, equivalent to $1000 \mathrm{~m}$ below seawater level (bswl)). The BES consisted of nonpolarized, graphite electrodes (hereby referred to as "snorkels"), electrically bridging anaerobic crude-oilcontaminated sediments with oxygenated, overlying seawaters. The side of the snorkel buried in sediment (i.e., the anode) collects electrons deriving from the (bio)oxidation of organic and inorganic compounds; owing to the existing redox gradient, electrons flow to the upper side of the snorkel to combine with oxygen $\left(\mathrm{O}_{2}\right)$ and protons to form water [14]. Originally, the concept of such a microbial electrochemical snorkel, a simplified design of a "short-circuited" microbial fuel cell (MFC), was proposed as a means to accelerate the anaerobic treatment of wastewater relative to a traditional MFC. More recently, the potential of this technology to sustain redox processes over long periods, with no need for continued maintenance, has attracted the interest for broader applications, including environmental remediation [15,16,23] and also metal recovery [24]. However, application of BES to environments exposed to enhanced $\mathrm{HP}$ (i.e., $5 \mathrm{MPa}$ ) has been explored marginally: Reimers et al. operated benthic microbial fuel cells at a cold seep ( 10 MPa $[25,26])$, and Kobayashi et al. conducted electromethanogenesis tests in laboratory-scale systems (5 $\mathrm{MPa}[27])$.

Here, we report on the first use of a BES at increased HP for bioremediation purposes. Increased HP negatively impacts microbial oil degradation under aerobic conditions. This is apparently due to a reduction of tricarboxylic acid (TCA) cycle rates, which act as a negative feedback on sustained hydrocarbon oxidation [28]. Microbial oil degradation in anaerobic sediments subjected to increased HP is thus expected to be further slowed. However, little to no investigation has been carried out so far on how to relieve this metabolic pressure and sustain oil bioremediation at deep-sea conditions. The aim of the present study was to test whether the inhibitory effects of increased HP on oil biodegradation rates could be alleviated at least in part by allowing microorganisms in sediments a preferential access to $\mathrm{O}_{2}$ via snorkels. Our hypothesis was that the oxidation of readily degradable petroleum constituents (e.g., alkanes) may rapidly deplete electron acceptors in the sediment, and potentially prevent the degradation of more recalcitrant components (e.g., polyaromatic hydrocarbons, PAHs) owing to the accumulation of toxic metabolites (e.g., $\mathrm{H}_{2} \mathrm{~S}$ following $\mathrm{SO}_{4}{ }^{2-}$ reduction). Results therefore describe snorkel impact on petroleum hydrocarbons removal (alkanes and total petroleum hydrocarbons (TPH)) and on the cycling of $\mathrm{SO}_{4}{ }^{2-}$ and $\mathrm{H}_{2} \mathrm{~S}$ as compared to nonconductive glass rods used as controls.

\section{Results and Discussion}

2.1. Bioelectrochemical Snorkels Enhance Alkanes Biodegradation at Deep-Sea and Ambient HP

Oil biodegradation was investigated in the $\mathrm{HP}$ range 0.1 to $10 \mathrm{MPa}$ (surface to $1000 \mathrm{~m} \mathrm{bswl}$ ), which coincides with the epi- and mesopelagic zone. Here, seawater is commonly subjected to high mixing (e.g., during winter, or due to convection from surface 
to deep waters [29]) and high rate of sinking particles from the surface (up to $10^{10}$ bacteria per gram, which can sink up to $\sim 4700 \mathrm{~m}$ bswl [30]). These deep seawaters and superficial seafloors are thus populated by a mixture of autochthonous (belonging in this environment) and allochthonous (originally from another environment, e.g., surface waters) prokaryotes. A fast, deep-sea bioremediation should theoretically rely on piezophilic (HP-requiring) oil-degrading prokaryotes; however, they do not appear to possess a competitive advantage at these mild depths. Seawaters [28,31-33] and sediments [34] collected from 1000 to $1500 \mathrm{bswl}$ and cultivated at in situ HP have lower oil degradation capacity than depressurized subsamples at $0.1 \mathrm{MPa}$. Estimates on the decrease of microbial oil degradation for every $1 \mathrm{MPa}$ increase indicate that cell division was reduced $5 \%$ in enriched seawater communities from $1100 \mathrm{~m}$ bswl using Macondo oil [33]; cell division and $\mathrm{CO}_{2}$ production were reduced 8 and $9 \%$, respectively, in synthetic communities originally collected 1000 $\mathrm{m}$ bswl using $n-\mathrm{C}_{20}$ [28]; and alkanes biodegradation was reduced $4 \%$ in sediments from $1100 \mathrm{~m}$ bswl using sweet Louisiana crude [34]. The fact that depressurization-enhanced microbial activity suggests that (1) piezophilic microorganisms did not predominate at these deep sampling sites, rather allochthonous from surface waters not adapted to increased HP constituted a large part of the microbial community; and (2) HP can severely impact oil degradation already at $10 \mathrm{MPa}$. Stimulation of microbial activity in environments exposed to these mild HPs appears crucial to support bioremediation.

In the present investigation, we used an electrochemical snorkel to enhance microbial oil metabolism in marine sediments. TPH removal was generally higher in the alkanes-rich Statfjord than in the alkanes-poor Danish Underground Consortium (Duc) oil (the relative decrease with respect to initial concentrations $\left(C / C_{0}\right)$ was $0.64<C / C_{0}<1.03$ vs. 0.85 $<\mathrm{C} / \mathrm{C}_{0}<1.04$; Figure 1A vs. Figure 1B). With Duc oil, no difference was observed in TPH or alkanes biodegradation when comparing snorkels to glass controls $(p>0.05$, HPS vs. HPC, or APS vs. APC, Figure 1A,C). However, with the alkanes-rich Statfjord oil, both TPH and alkanes were biodegraded more when using snorkels at $0.1 \mathrm{MPa}(p<0.001$, APS vs. APC, Figure 1B,D), a result also observed for alkanes at $10 \mathrm{MPa}(p=0.004$, HPS vs. HPC, Figure 1D). Hence, bioelectrochemical snorkels could significantly enhance the removal of readily degradable hydrocarbons such as alkanes at deep-sea HPs within only seven weeks. The quality and quantity of the growth substrate can affect the microbial response to increased HP $[35,36]$. Here, the higher initial concentration of alkanes (315 vs. $139 \mu \mathrm{g} \mathrm{g}_{\mathrm{DW}}{ }^{-1}$, Statfjord vs. Duc, Figure 1, Table S1) may have been a relevant factor for the sustained electrobioremediation at $10 \mathrm{MPa}$. Nonetheless, increased HP had a negative impact. For every $1 \mathrm{MPa}$ increase, alkanes biodegradation was significantly reduced: $5 \%$ with Duc oil with snorkels ( $2 \%$ with glass controls, albeit not significantly), and $5 \%$ and $11 \%$ with Statfjord oil in snorkels and glass controls, respectively $(p<0.05$, Figure 1$)$. Despite sediments were collected at $30 \mathrm{~m}$ bswl, HP inhibition rates were thus comparable with those of samples from 1000 to $1500 \mathrm{~m}$ bswl $[28,33,34]$. This further confirms that microorganisms that are sensitive to increased HP (piezosensitive) and piezophiles are intermixed in the oceans [29]. Predominance of piezophiles underwater arises with long-term exposure to enhanced HP, as in deep, stratified waters [29]. Similarly, long-term exposure to petroleum may favor the evolutionary microbial adaptation to the fast, effective use of oil as a carbon and energy source. A better understanding of the metabolic requirements for sustained oil biodegradation at increased HP may be found at, e.g., deep hydrocarbon seeps [37] or chronically polluted deep-sea sites following anthropogenic spills. As the snorkel's application for longer incubations ( $>1$ year) efficiently reduced TPHs at ambient pressure $[14,15]$, electrobioremediation of the most recalcitrant petroleum components should be tested with deep-sea samples from these long-term contaminated sites. 


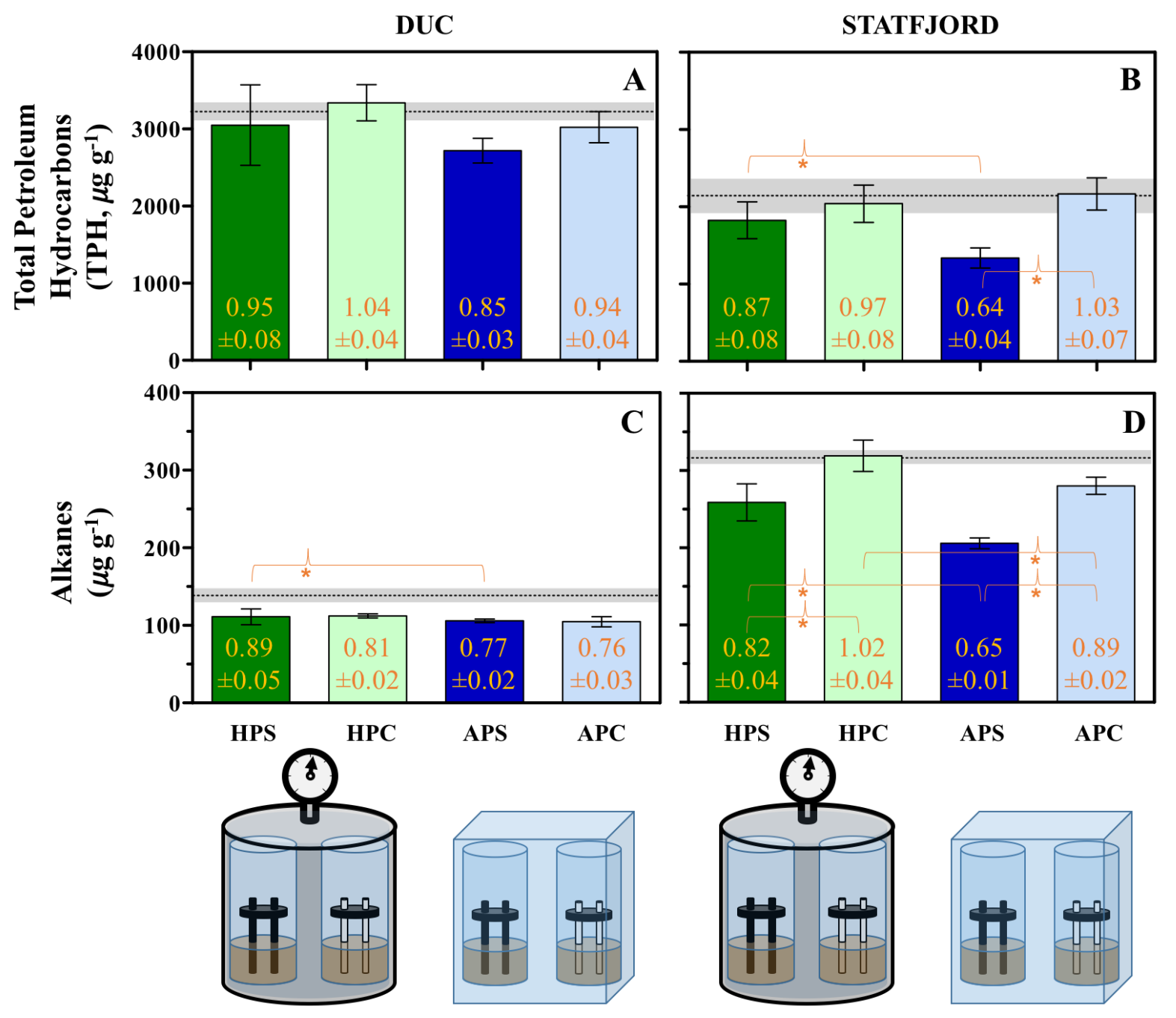

Figure 1. Final concentration ( $\mu \mathrm{g} \mathrm{g}^{-1}$ dry weight sediment) of total petroleum hydrocarbons $(\mathbf{A}, \mathbf{B})$ and alkanes (between $\mathrm{C}_{8}$ and $\left.\mathrm{C}_{33} ;(\mathbf{C}, \mathbf{D})\right)$ at the end of 7 weeks of incubation in sediments contaminated with either Danish Underground Consortium (Duc) $(\mathbf{A}, \mathbf{C})$ or Statfjord (B,D) oil ( $\mathrm{n}=3$; bars represent standard errors). Contamination levels at time zero are reported as horizontal dotted lines, with the grey areas representing the standard error ( $n=3$; data in Table S1). Degradation was assessed as the relative decrease with respect to the concentration at time zero $\left(C / C_{0}\right)$, and is reported in orange for each condition. Abbreviations reported in the graph: HPS, high pressure with snorkels; HPC, high pressure with glass controls; APS, ambient pressure with snorkels; APC, ambient pressure with glass controls. Asterisks indicate statistically significant difference between the bars located at the two extremes of the parenthesis.

\subsection{Bioelectrochemical Snorkels Regenerate $\mathrm{SO}_{4}{ }^{2-}$ in Sediments at Deep-Sea and Ambient HP}

Aside growth substrate, microbial response to increased HP is affected by, e.g., temperature [38] and nutrient availability (quality and quantity) [39]. At low and middle latitudes, temperature in epi- and mesopelagic seawaters decreases along a permanent thermocline from as much as 30 to $\sim{ }^{\circ} \mathrm{C}$ [40]. In this investigation, temperature was kept at $14{ }^{\circ} \mathrm{C}$ to test the sole impact of increased HP. Concerning nutrients, oxidation of petroleum hydrocarbons may use $\mathrm{O}_{2}$ as terminal electron acceptors in seawater, or Fe[III] and $\mathrm{SO}_{4}{ }^{2-}$ in anaerobic sediments. $\mathrm{O}_{2}$ in epi- and mesopelagic seawaters decreases from as much as $350 \mu \mathrm{mol} \mathrm{kg}{ }^{-1}$ (or $11.2 \mathrm{mg} \mathrm{L}^{-1}$ ) to a range $40-240 \mu \mathrm{mol} \mathrm{kg}{ }^{-1}$ (or $1.3-7.7 \mathrm{mg} \mathrm{L}^{-1}$ ) according to the latitude [40]. In this investigation, values ranged between 8 and $0.03 \mathrm{mg} \mathrm{L}^{-1}$ (beginning and end of the incubation, respectively). While $\mathrm{O}_{2}$ in seawaters is continuously replenished by water circulation and vertical diffusion through the water column, Fe[III] and $\mathrm{SO}_{4}{ }^{2-}$ in anaerobic sediments are limited reservoirs whose depletion can limit microbial metabolism [2]. In this investigation, application of the snorkel to oil-contaminated 
sediments regenerated $\mathrm{SO}_{4}{ }^{2-}$, using $\mathrm{O}_{2}$ in seawater as the ultimate electron acceptor. At the end of the incubation, all sediments were anoxic $2 \mathrm{~mm}$ below the sediment surface. Total sulfide $\left(\Sigma \mathrm{H}_{2} \mathrm{~S}\right.$, equal to $\left.\left[\mathrm{H}_{2} \mathrm{~S}\right]+\left[\mathrm{HS}^{-}\right]+\left[\mathrm{S}^{2-}\right]\right)$ microprofiles were assessed in contaminated sediments with either crude oil (Figure 2A-D). The higher TPH biodegradation trend observed with Statfjord as compared to Duc oil (Figure 1) was mirrored by a higher $\Sigma \mathrm{H}_{2} \mathrm{~S}$ accumulation (Figure 2A-D). This suggests that electrons derived from the oxidation of hydrocarbons were primarily used to reduce $\mathrm{SO}_{4}{ }^{2-}$ thereby generating $\mathrm{H}_{2} \mathrm{~S}$, with the alkanes-rich Statfjord oil accumulating more $\mathrm{H}_{2} \mathrm{~S}$.

Notably, $\Sigma \mathrm{H}_{2} \mathrm{~S}$ was substantially lower in the presence of snorkels than in the respective glass controls at equivalent HP $(p<0.001$, HPS vs. HPC, Figure $2 \mathrm{~A}, \mathrm{C}$; or APS vs. APC, Figure 2B,D). This indicates that $\mathrm{H}_{2} \mathrm{~S}$ rapidly reacted with the anodic portion of snorkels buried in sediments. Anodic $\mathrm{H}_{2} \mathrm{~S}$ oxidation was suggested to be advantageous for microbial activity [41-43]: first, because $\mathrm{H}_{2} \mathrm{~S}$ scavenging reduces its toxicity to microorganisms [4]. This was most evident when using the alkane-rich Statfjord oil, where the higher abatement of $\Sigma \mathrm{H}_{2} \mathrm{~S}$ with snorkels $(p<0.001$, Figure 2C,D) was consistent with the enhanced reduction of TPH (Figure 1B) and, particularly, alkanes (Figure 1D). Consistently lower $\Sigma \mathrm{H}_{2} \mathrm{~S}$ levels in the presence of snorkels as compared to glass controls across all conditions indicated that snorkels worked equally well at ambient and increased HP within a large range of $\Sigma \mathrm{H}_{2} \mathrm{~S}$ concentrations $\left(p<0.001\right.$, Figure 2A-D). Lower $\Sigma \mathrm{H}_{2} \mathrm{~S}$ levels at increased HP as compared to ambient pressure confirmed the decrease in $\mathrm{SO}_{4}{ }^{2-}$-reducing activity at 10 $\mathrm{MPa}$, as mirrored in the lower alkanes degradation $(p<0.05$ except for DUC HPC vs. APC, Figure 1C,D).

The second advantage of $\mathrm{H}_{2} \mathrm{~S}$ oxidation at the anode is that it regenerates oxidized sulfur species $[16,44]$ (e.g., $\mathrm{SO}_{4}{ }^{2-}$ ), which may be used by $\mathrm{SO}_{4}{ }^{2-}$ or sulfur-reducing bacteria as electron acceptors $[7,12,41]$. In contaminated sediments, this would circumvent the risk for electron acceptor depletion and support prolonged periods of microbial, $\mathrm{SO}_{4}{ }^{2-}$-driven hydrocarbon degradation, a critical advantage for remote deep seafloor. Accumulation of $\mathrm{H}_{2} \mathrm{~S}$ in sediments implied that $\mathrm{SO}_{4}{ }^{2-}$ was used as an electron acceptor, as in fact observed in all incubations (Figure 2E,F). Nonetheless, application of conductive snorkels rather than nonconductive controls resulted in lower $\mathrm{SO}_{4}{ }^{2-}$ consumptions $(p<0.05$ except for Statfjord HPS vs. HPC, Figure $2 \mathrm{E}, \mathrm{F}$ ). Together with $\Sigma \mathrm{H}_{2} \mathrm{~S}$ microprofiles (Figure $2 \mathrm{~A}-\mathrm{D}$ ), this confirms that snorkels contributed to a sustained $\mathrm{SO}_{4}{ }^{2-}$ regeneration irrespective of the HP applied.

Electrons generated by $\mathrm{H}_{2} \mathrm{~S}$ oxidation at the anode eventually reach the cathode (i.e., the snorkel side in contact with overlying waters) where they react with $\mathrm{O}_{2}$ as the ultimate electron acceptor. The cumulative $\mathrm{O}_{2}$ consumption in the water column above contaminated sediments was generally higher in the presence of snorkels than in the glass controls at equivalent HP (HPS vs. HPC, or APS vs. APC, Figure 2G,H). As cell densities in the water column were comparable in snorkel and glass controls $(p>0.05$, Figure S1), the difference in $\mathrm{O}_{2}$ consumption in overlying waters depended on the electrochemical connection with electron donors in sediments provided by snorkels. Cumulative respiration in overlying waters within $\sim 50$ days $\left(14-15 \mathrm{~mL} \mathrm{O}_{2}\right.$ per graphite rod; $\left.14{ }^{\circ} \mathrm{C}, 0.1 \mathrm{MPa}\right)$ was comparable with other oil-contaminated sediments $\left(7-10 \mathrm{~mL} \mathrm{O}_{2}\right.$ per graphite rod; $20^{\circ} \mathrm{C}$ and $0.1 \mathrm{MPa}$ [14]). Estimates on the $\mathrm{O}_{2}$ consumption owing to electrochemical $\mathrm{H}_{2} \mathrm{~S}$ oxidation alone accounted for no more than $1 \mathrm{mg} \mathrm{O}_{2} \mathrm{~L}^{-1}$, explaining $10 \%$ to $\sim 40 \%$ of the differential $\mathrm{O}_{2}$ consumption between snorkels and glass rods, with either crude oil and HP (see Supplementary Information). This suggests that, along with mediating $\mathrm{H}_{2} \mathrm{~S}$ oxidation back to $\mathrm{SO}_{4}{ }^{2-}$, snorkels served as electron sinks for other reduced (organic and/or inorganic) substances in contaminated sediments, possibly including petroleum hydrocarbons or metabolic intermediates derived from hydrocarbon anaerobic degradation. 


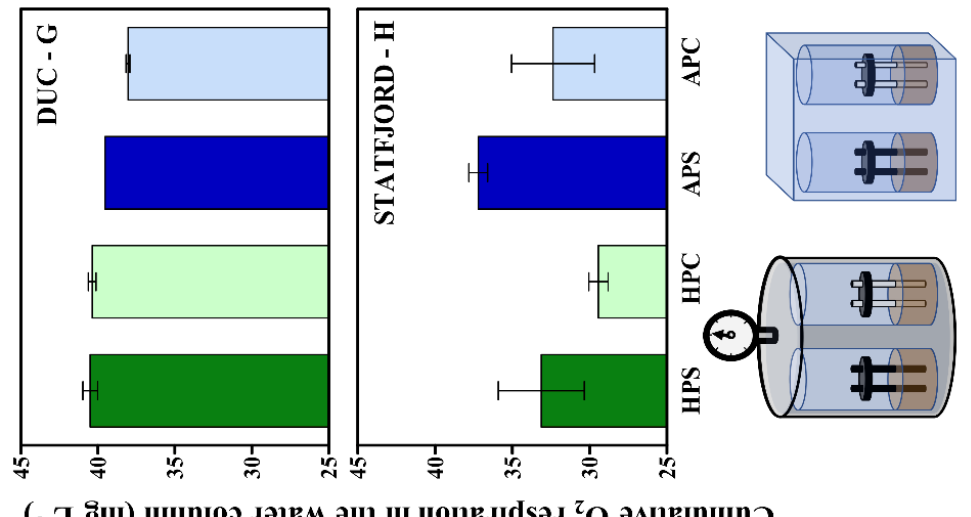

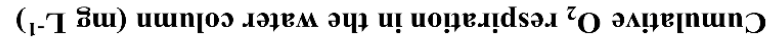

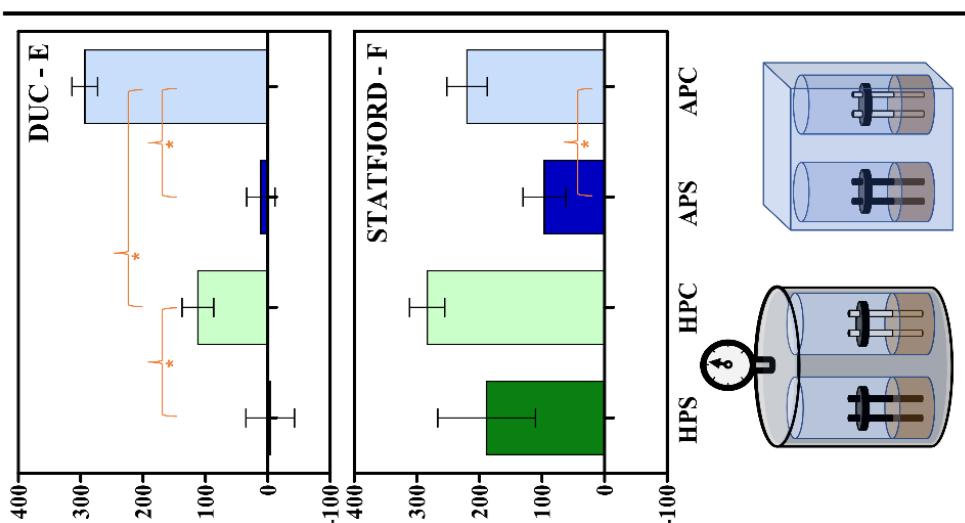

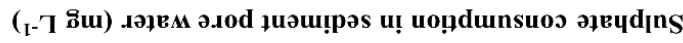

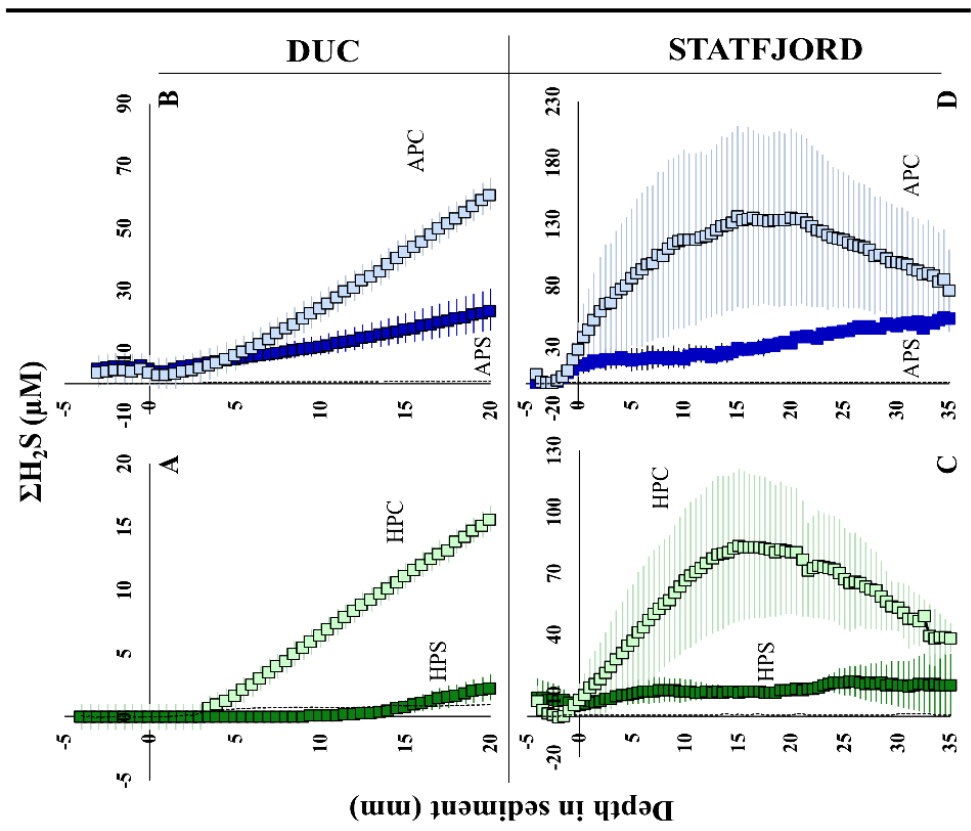

Figure 2. Microprofiles of total hydrogen sulfide $\left(\mathrm{\Sigma H}_{2} \mathrm{~S}=\left[\mathrm{H}_{2} \mathrm{~S}\right]+\left[\mathrm{HS}^{-}\right]+\left[\mathrm{S}^{2-}\right]\right)$ concentrations $(A-D)$, sulfate $\left(\mathrm{SO}_{4}{ }^{2-}\right)$ in sediment pore water $(\mathbf{E}, \mathbf{F})$ and cumulative $\mathrm{O}_{2}$ respiration in seawater overlying contaminated sediments at the end of 7 weeks of incubation in sediments contaminated with either Duc (A,B,E,G) or Statfjord $(\mathbf{C}, \mathbf{D}, \mathbf{F}, \mathbf{H})$ oil ( $\mathrm{n}=3$; bars represent standard errors). Microprofiles of $\Sigma \mathrm{H}_{2} \mathrm{~S}$ at time zero (A-D) are indicated as dotted lines. Initial $\mathrm{SO}_{4}{ }^{2-}$ concentrations $(\mathbf{E}, \mathbf{F})$ are indicated as horizontal dotted lines, with the grey areas representing the standard error $(n=3)$. The cumulative amount of $\mathrm{O}_{2}$ in seawater provided through the 7 weeks of incubation was $\sim 55 \mathrm{mg} \mathrm{L}^{-1}$. Abbreviations reported in the graph: HPS, high pressure with snorkels; HPC, high pressure with glass controls; APS, ambient pressure with snorkels; APC, ambient pressure with glass controls. Asterisks indicate statistically significant difference between the bars located at the two extremes of the parenthesis. 


\section{Materials and Methods}

\subsection{Sediment Sampling}

Sediment samples were collected from Aarhus Bay (Denmark) onboard the Aurora Research vessel (Aarhus University), station M5 (56 $06^{\prime} 20^{\prime \prime} \mathrm{N}, 10^{\circ} 27^{\prime} 48^{\prime \prime} \mathrm{E} ; 30 \mathrm{~m}$ bswl), using a box corer. Onboard, the upper 10-12 cm of sediment was discarded to exclude large burrowing animals. The sediment was sieved (mesh $0.5 \mathrm{~mm}$ ) to remove solid residues that could interfere with microsensor measurements, homogenized and stored at $14{ }^{\circ} \mathrm{C}$ in airtight bags for three weeks. Exposure to air was minimized during handling procedures. The initial concentration of nitrite $\left(\mathrm{NO}_{2}\right)$ and nitrate $\left(\mathrm{NO}_{3}\right)$ in the pore water of incubated sediments was below detection limit $(<10 \mu \mathrm{M})$, while that of $\mathrm{Fe}^{2+}$ ranged between 6.3 and $16 \mu \mathrm{M}$.

\subsection{Reactors Configuration}

The sediment was artificially contaminated with crude oil and incubated for a total of seven weeks. Experiments used either Duc oil or Statfjord oil. The sediment contamination procedure [16,45], minimized the chemical and microbiological perturbation of the samples while allowing a homogeneous distribution of the oil in the whole sediment mass. Contaminated sediment was transferred into a glass cylinder (external diameter $4.2 \mathrm{~cm}$, glass thickness $0.2 \mathrm{~cm}$, height $33.5 \mathrm{~cm}$ ). The final contamination (expressed as TPHs) for Duc and Statfjord oil was $3.2 \pm 0.2$ and $2.1 \pm 0.2 \mathrm{mg}$ TPH per gram of sediment dry weight $\left(\mathrm{g}^{-1}\right.$ $\mathrm{DW})$, respectively (Table S1). These two crude oils were selected for their different content in alkanes, which was $\sim 4.6$ times lower in Duc $(4.32 \% \pm 0.08)$ as compared to Statfjord oil $(14.92 \% \pm 1.09$; Table S1). The final volume of contaminated sediment was $\sim 110 \mathrm{~mL}$.

Bioelectrochemical petroleum degradation was assessed by preparing glass cylinders with either conductive graphite rods (snorkels) or nonconductive glass rods (controls), and applying either ambient $(0.1 \mathrm{MPa})$ or increased (10 MPa) HP. Four types of cylinders were prepared: (1) glass controls at ambient pressure, (2) snorkels at ambient pressure, (3) glass controls at increased HP and (4) snorkels at increased HP. In snorkel treatments, two graphite rods (>99.9995\% purity; Alfa Aesar, Milan, Italy; diameter $6.15 \mathrm{~mm}$, length $150 \mathrm{~mm}$ ) were embedded into the sediment for $8 \mathrm{~cm}$, with the remaining $7 \mathrm{~cm}$ above the sediment surface. The two rods were connected at the top by a carbon felt disc (thickness $10 \mathrm{~mm}$, carbon content $>97 \%$, specific resistance $0.18-0.22 \Omega$ per $\mathrm{cm}$; Hi-Tech Carbon Co., Limited-China) to extend the cathodic electrode surface. Control treatments had an identical set up, except for the replacement of conductive graphite rods with nonconductive glass rods of comparable dimensions (diameter $6.1 \mathrm{~mm}$, height $150 \mathrm{~mm}$ ).

Glass cylinders were filled with $\sim 200 \mathrm{~mL}$ of sterile, artificial seawater (salinity $30 \%$; Red Sea Salts, Red Sea Fish Pharm Ltd., Eilat, Israel). Seawater was oxygenated at the beginning of the experiment by flushing sterile air ( $98 \% \mathrm{O}_{2}$ saturation). $\mathrm{O}_{2}$ concentration was monitored via fiber-optic sensors connected to a reader (PyroScience, Germany). Cylinders were sealed at each side with rubber stoppers. No gas phase was left inside the cylinders. Experiments were conducted at $14 \pm 2{ }^{\circ} \mathrm{C}$, and cylinders wrapped in aluminum foil to maintain darkness. At increased HP, cylinders were placed in a $5 \mathrm{~L}$ high-pressure reactor (capacity 0.1 to $60 \mathrm{MPa}$; Dustec Hochdrucktechnik GmbH, Germany) operated at $10 \mathrm{MPa}$. HP was changed manually via a HP pump (Enerpac, Netherlands) following compression and decompression rates, as described in [46]. As all experiments were conducted in three independent replicates, a total of 24 cylinders of $\sim 310 \mathrm{~mL}$ each were tested for crude oil biodegradation, with six additional glass cylinders (three for each crude oil) entirely sampled before incubation to determine initial time points.

\subsection{Sampling Procedure}

Cylinders were sampled every seven days for $\mathrm{O}_{2}$ concentration in seawater via fiber optics at 17,9 and $1 \mathrm{~cm}$ above the sediment surface. Seawater was then reoxygenated to $98 \%$ of $\mathrm{O}_{2}$ saturation, and the cylinders incubated for another seven days. After seven weeks of operation, following $\mathrm{O}_{2}$ measurement, high resolution microprofiles of $\mathrm{H}_{2} \mathrm{~S}, \mathrm{pH}$ 
and $\mathrm{O}_{2}$ were conducted in the sediments. Afterwards, bulk sediments were sampled to determine TPH and alkanes, and $\mathrm{SO}_{4}{ }^{2-}$ in the pore water.

\subsection{Analytical Procedures}

Cell numbers were assessed by flow cytometry as described in [46]. TPH and $n$ alkanes quantification in sediments was performed by gas chromatography combined with mass spectrometry (GC-MS) as reported elsewhere [16]. In brief, sediment samples (approximately $10 \mathrm{~g}$ ) were air dried overnight and extracted with a Thermo Scientific ASE (DIONEX ASE 150) using a dichloromethane (DCM): hexane $(1: 9, v / v)$ mixture at $100{ }^{\circ} \mathrm{C}$ and a system pressure of $1500 \mathrm{psi}$. The extract was evaporated to a final volume of $5 \mathrm{~mL}$ under a gentle nitrogen stream. A sample of the extract $(1 \mu \mathrm{L})$ was then injected (in pulsed splitless mode) into a GC-MS (PerkinElmer Clarus 680/600; column: HP-5 MS [Agilent] $30 \mathrm{~m}$, ID $0.25 \mathrm{~mm}, 0.25 \mathrm{~mm}$ film thickness; carrier gas: helium at $1 \mathrm{~mL} / \mathrm{min}$; injector temperature: $280^{\circ} \mathrm{C}$; oven temperature program: initial temperature $40{ }^{\circ} \mathrm{C}, 18^{\circ} \mathrm{C} / \mathrm{min}$ to $250{ }^{\circ} \mathrm{C}, 10^{\circ} \mathrm{C} / \mathrm{min}$ to $280^{\circ} \mathrm{C}$, hold for $17 \mathrm{~min}$; MS-scan 30-600, 2-32 min).

TPHs were determined by summing up both the unresolved and resolved components eluting from the GC capillary column between the retention times of $n-\mathrm{C}_{8}$ and of $n-\mathrm{C}_{40}$, using solutions of diesel motor oil and diesel mineral oil in hexane as calibration standards. Degradation was assessed as the relative decrease with respect to initial concentrations $\left(\mathrm{C} / \mathrm{C}_{0}\right)$. Alkanes calibration was performed with standards $\left(\mathrm{C}_{8}-\mathrm{C}_{40}\right.$ Alkanes Calibration Standard, Sigma-Aldrich). Sediment not used for petroleum analysis was centrifuged at $8000 \mathrm{rpm}$ for $15 \mathrm{~min}$ and $\sim 1.5 \mathrm{~mL}$ of supernatant sampled to determine $\mathrm{SO}_{4}{ }^{2-}$ in the pore water by ion chromatography (Dionex IC-2500, Thermo Fisher Scientific).

\subsection{Microsensor Measurements}

High-resolution depth profiles of $\mathrm{H}_{2} \mathrm{~S}, \mathrm{pH}$ and $\mathrm{O}_{2}$ were recorded with microelectrodes built at Aarhus University [47-49], microprofiling and microsensor calibrations were conducted as described in [50]. Microprofiles were recorded at 100-400 $\mu \mathrm{m}$ vertical resolution and measured at $\sim 2 \mathrm{~cm}$ from graphite or glass rods. A reference electrode (REF201 Red Rod electrode; Radiometer Analytical, Denmark) was used for $\mathrm{pH}$ measurements. Total hydrogen sulfide $\left(\mathrm{\Sigma H}_{2} \mathrm{~S}=\left[\mathrm{H}_{2} \mathrm{~S}\right]+\left[\mathrm{HS}^{-}\right]+\left[\mathrm{S}^{2-}\right]\right)$ concentrations were calculated at each depth from the measured $\mathrm{H}_{2} \mathrm{~S}$ and $\mathrm{pH}$ values [49].

\subsection{Statistical Analysis}

Results are the mean value of experiments made in three independent replicates. Deviation was determined as standard error. Statistical significance was assessed with a t-test, two-tailed, 95\% confidence interval.

\section{Conclusions}

Application of BESs has great potential for the biodegradation of hazardous compounds in anaerobic, electron-acceptor-limited sediments [51]. Here we show that in sediments exposed to $10 \mathrm{MPa}$, snorkels could accelerate alkanes biodegradation within only seven weeks (from 1.02 to $0.82, \mathrm{C} / \mathrm{C}_{0}$ ), while reducing toxic $\mathrm{H}_{2} \mathrm{~S}$ accumulation (up to $85 \%$, at the highest concentrations) and regenerating $\mathrm{SO}_{4}{ }^{2-}$ (up to the initial concentration). Both factors are crucial to degrade petroleum hydrocarbons over extended periods of time, particularly in remote deep seafloors.

Supplementary Materials: The following are available online at https:/ /www.mdpi.com/2073-4 344/11/2/263/s1, Supplementary Information; Figure S1: Cell number in the water column at the end of 7 weeks of incubation in sediments contaminated with either Duc or Statfjord oil; Table S1: Duc and Statfjord crude oil alkanes profiles in contaminated sediments at Time zero; Table S2: Estimation of the total $\mathrm{H}_{2} \mathrm{~S}$ (nmoles) accumulated in sediments, which were incubated with either Duc or Statfjord crude oil, with snorkels or glass controls, at 10 or 0.1 MPa; Table S3: Estimates of the total $\mathrm{O}_{2}$ respiration in seawater due to electrochemical oxidation of $\mathrm{H}_{2} \mathrm{~S}$ in sediments, and of the 
relative contribution to the electrochemical $\mathrm{O}_{2}$ respiration to the total, in marine sediments incubated with either Duc or Statfjord crude oil, with snorkels or glass controls, at 10 or $0.1 \mathrm{MPa}$.

Author Contributions: Experimental design, A.S., F.A. and U.M.; high pressure incubations, E.P. and A.S.; total $\mathrm{H}_{2} \mathrm{~S}$ microprofiles, E.P. and U.M.; petroleum hydrocarbons analysis, E.P. and C.C.V.; bulk sulfate measurements, E.P. and U.M.; $\mathrm{O}_{2}$ measurements, E.P., A.S. and U.M.; data analysis, all authors; manuscript preparation, A.S. and F.A.; contribution to manuscript final version, all authors. All authors have read and agreed to the published version of the manuscript.

Funding: U.M. was supported by the Marie Sklodowska-Curie programme (grant 656385) and the Danish National Research Foundation (grant DNRF104).

Acknowledgments: We thank Lars Borregaard-Pedersen for microsensor construction and technical support. Flow cytometry was performed at the FACS Core Facility, Aarhus University. A.S. is grateful to Kasper U. Kjeldsen and Hans Røy for their support.

Conflicts of Interest: The authors declare no conflict of interest.

\section{References}

1. Meckenstock, R.U.; Boll, M.; Mouttaki, H.; Koelschbach, J.S.; Cunha Tarouco, P.; Weyrauch, P.; Dong, X.; Himmelberg, A.M. Anaerobic Degradation of Benzene and Polycyclic Aromatic Hydrocarbons. J. Mol. Microbiol. Biotechnol. 2016, 26, 92-118. [CrossRef]

2. Meckenstock, R.U.; Elsner, M.; Griebler, C.; Lueders, T.; Stumpp, C.; Aamand, J.; Agathos, S.N.; Albrechtsen, H.J.; Bastiaens, L.; Bjerg, P.L.; et al. Biodegradation: Updating the concepts of control for microbial cleanup in contaminated aquifers. Environ. Sci. Technol. 2015, 49, 7073-7081. [CrossRef]

3. White, C.; Gadd, G.M. Mixed sulphate-reducing bacterial cultures for bioprecipitation of toxic metals: Factorial and responsesurface analysis of the effects of dilution rate, sulphate and substrate concentration. Microbiology 1996, 142, 2197-2205. [CrossRef]

4. O'Flaherty, V.; Mahony, T.; O'Kennedy, R.; Colleran, E. Effect of pH on growth kinetics and sulphide toxicity thresholds of a range of methanogenic, syntrophic and sulphate-reducing bacteria. Process Biochem. 1998, 33, 555-569. [CrossRef]

5. Rabaey, K.; Rodriguez, J.; Blackall, L.L.; Keller, J.; Gross, P.; Batstone, D.; Verstraete, W.; Nealson, K.H. Microbial ecology meets electrochemistry: Electricity-driven and driving communities. ISME J. 2007, 1, 9-18. [CrossRef]

6. Zhang, T.; Gannon, S.M.; Nevin, K.P.; Franks, A.E.; Lovley, D.R. Stimulating the anaerobic degradation of aromatic hydrocarbons in contaminated sediments by providing an electrode as the electron acceptor. Environ. Microbiol. 2010, 12, 1011-1020. [CrossRef]

7. Rakoczy, J.; Feisthauer, S.; Wasmund, K.; Bombach, P.; Neu, T.R.; Vogt, C.; Richnow, H.H. Benzene and sulfide removal from groundwater treated in a microbial fuel cell. Biotechnol. Bioeng. 2013, 110, 3104-3113. [CrossRef]

8. Wei, M.; Harnisch, F.; Vogt, C.; Ahlheim, J.; Neu, T.R.; Richnow, H.H. Harvesting electricity from benzene and ammoniumcontaminated groundwater using a microbial fuel cell with an aerated cathode. RSC Adv. 2015, 5, 5321-5330. [CrossRef]

9. Luo, H.P.; Liu, G.L.; Zhang, R.D.; Jin, S. Phenol degradation in microbial fuel cells. Chem. Eng. J. 2009, 147, 259-264. [CrossRef]

10. Feng, C.H.; Huang, L.Q.; Yu, H.; Yi, X.Y.; Wei, C.H. Simultaneous phenol removal, nitrification and denitrification using microbial fuel cell technology. Water Res. 2015, 76, 160-170. [CrossRef] [PubMed]

11. Hedbavna, P.; Rolfe, S.A.; Huang, W.E.; Thornton, S.F. Biodegradation of phenolic compounds and their metabolites in contaminated groundwater using microbial fuel cells. Bioresour. Technol. 2016, 200, 426-434. [CrossRef]

12. Daghio, M.; Vaiopoulou, E.; Patil, S.A.; Suarez-Suarez, A.; Head, I.M.; Franzetti, A.; Rabaey, K. Anodes Stimulate Anaerobic Toluene Degradation via Sulfur Cycling in Marine Sediments. Appl. Environ. Microbiol. 2016, 82, 297-307. [CrossRef]

13. Sherafatmand, M.; Ng, H.Y. Using sediment microbial fuel cells (SMFCs) for bioremediation of polycyclic aromatic hydrocarbons (PAHs). Bioresour. Technol. 2015, 195, 122-130. [CrossRef]

14. Viggi, C.C.; Presta, E.; Bellagamba, M.; Kaciulis, S.; Balijepalli, S.K.; Zanaroli, G.; Petrangeli Papini, M.; Rossetti, S.; Aulenta, F. The "Oil-Spill Snorkel": An innovative bioelectrochemical approach to accelerate hydrocarbons biodegradation in marine sediments. Front. Microbiol. 2015, 6, 881.

15. Viggi, C.C.; Matturro, B.; Frascadore, E.; Insogna, S.; Mezzi, A.; Kaciulis, S.; Sherry, A.; Mejeha, O.K.; Head, I.M.; Vaiopoulou, E.; et al. Bridging spatially segregated redox zones with a microbial electrochemical snorkel triggers biogeochemical cycles in oil-contaminated River Tyne (UK) sediments. Water Res. 2017, 127, 11-21. [CrossRef] [PubMed]

16. Marzocchi, U.; Palma, E.; Rossetti, S.; Aulenta, F.; Scoma, A. Parallel artificial and biological electric circuits power petroleum decontamination: The case of snorkel and cable bacteria. Water Res. 2020, 173, 115520. [CrossRef]

17. Scoma, A.; Yakimov, M.M.; Boon, N. Challenging Oil Bioremediation at Deep-Sea Hydrostatic Pressure. Front. Microbiol. 2016, 7. [CrossRef]

18. Jernelöv, A. How to defend against future oil spills. Nature 2010, 466, 182-183. [CrossRef] [PubMed]

19. The Federal Interagency Solutions Group, Oil Budget Calculator Science and Engineering Team. Oil Budget Calculator (Deepwater Horizon); Technical Documentation; The Federal Interagency Solutions Group, Oil Budget Calculator Science and Engineering Team: Washington, DC, USA, 2010. 
20. NOAA/Hazardous Materials Response and Assessment Division Seattle, Washington. Oil Spill Case Histories; NOAA/Hazardous Materials Response and Assessment Division Seattle, Washington: Silver Spring, MD, USA, 1992; pp. 1-224.

21. Michel, J.; Gilbert, T.; Etkin, D.S.; Urban, R.; Waldron, J.; Blocksidge, C.T. Potentially Polluting Wrecks in Marine Waters. In Proceedings of the 2005 International Oil Spill Conference, Miami Beach, FL, USA, 15-19 May 2005; pp. 1-38.

22. Mugge, R.; Brock, M.; Salerno, J.L.; Damour, M.; Church, R.A.; Lee, J.S.; Hamdan, L.J. Deep-Sea Biofilms, Historic Shipwreck Preservation and the Deepwater Horizon Spill. Front. Mar. Sci. 2019, 6. [CrossRef]

23. Hoareau, M.; Erable, B.; Bergel, A. Microbial electrochemical snorkels (MESs): A budding technology for multiple applications. A mini review. Electrochem. Comm. 2019, 104, 106473. [CrossRef]

24. Mitov, M.; Bardarov, I.; Chorbadzhiyska, E.; Kostov, K.L.; Hubenova, Y. First evidence for applicability of the microbial electrochemical snorkel for metal recovery. Electrochem. Comm. 2021, 122, 106889. [CrossRef]

25. Reimers, C.E.; Girguis, P.; Stecher, H.A.; Tender, L.M.; Ryckelynck, N.; Whaling, P. Microbial fuel cell energy from an ocean cold seep. Geobiology 2006, 4, 123-136. [CrossRef]

26. Nielsen, M.E.; Reimers, C.E.; White, H.K.; Sharma, S.; Girguis, P.R. Sustainable energy from deep ocean cold seeps. Energy Environ. Sci. 2008, 1, 584-593. [CrossRef]

27. Kobayashi, H.; Nagashima, A.; Kouyama, M.; Fu, Q.; Ikarashi, M.; Maeda, H.; Sato, K. High-pressure thermophilic electromethanogenic system producing methane at $5 \mathrm{MPa}, 55^{\circ} \mathrm{C}$. J. Biosci. Bioeng. 2017, 124, 327-332. [CrossRef]

28. Scoma, A.; Heyer, R.; Rifai, R.; Dandyk, C.; Marshall, I.; Kerckhof, F.M.; Marietou, A.; Boshker, H.T.S.; Meysman, F.J.R.; Malmos, K.G.; et al. Reduced TCA cycle rates at high hydrostatic pressure hinder hydrocarbon degradation and obligate oil degraders in natural, deep-sea microbial communities. ISME J. 2018, 13, 1004-1018. [CrossRef]

29. Tamburini, C.; Boutrif, M.; Garel, M.; Colwell, R.R.; Deming, J.W. Prokaryotic responses to hydrostatic pressure in the ocean-A review. Environ. Microbiol. 2013, 15, 1262-1274. [CrossRef] [PubMed]

30. Deming, J. Bacterial growth in deep-sea sediment trap and boxcore samples. Mar. Ecol. Prog. Ser. 1985, 25, 305-312. [CrossRef]

31. Schwarz, J.R.; Walker, J.D.; Colwell, R.R. Deep-Sea Bacteria: Growth and Utilization of Hydrocarbons at Ambient and In Situ Pressure. Appl. Microbiol. 1974, 28, 982-986. [CrossRef]

32. Schwarz, J.R.; Walker, J.D.; Colwell, R.R. Deep-sea bacteria: Growth and utilization on n-hexadecane at in situ temperature and pressure. Can. J. Microbiol. 1975, 21, 682-687. [CrossRef] [PubMed]

33. Marietou, A.; Chastain, R.; Beulig, F.; Scoma, A.; Hazen, T.C.; Bartlett, D.H. The Effect of Hydrostatic Pressure on Enrichments of Hydrocarbon Degrading Microbes from the Gulf of Mexico Following the Deepwater Horizon Oil Spill. Front. Microbiol. 2018, 9 , 808. [CrossRef]

34. Nguyen, U.T.; Lincoln, S.A.; Valladares Juarez, A.G.; Schedler, M.; Macalady, J.L.; Muller, R.; Freeman, K.H. The influence of pressure on crude oil biodegradation in shallow and deep Gulf of Mexico sediments. PLoS ONE 2018, 13, e0199784. [CrossRef] [PubMed]

35. Jannasch, H.W.; Taylor, C.D. Deep-sea Microbiology. Ann. Rev. Microbiol. 1984, 38, 487-514. [CrossRef]

36. Yayanos, A.A.; Chastain, R. The influence of nutrition on the physiology of piezophilic bacteria. In Proceedings of the 8th International Symposium on Microbial Ecology, Halifax, NS, Canada, 9-14 August 1998; p. 6.

37. Scoma, A.; Yakimov, M.M.; Daffonchio, D.; Boon, N. Self-healing capacity of deep-sea ecosystems affected by petroleum hydrocarbons: Understanding microbial oil degradation at hydrocarbon seeps is key to sustainable bioremediation protocols. EMBO Rep. 2017, 18, 868-872. [CrossRef] [PubMed]

38. Yayanos, A.A. Evolutional and ecological implications of the properties of deep-sea barophilic bacteria. Proc. Natl. Acad. Sci. USA 1986, 83, 9542-9546. [CrossRef]

39. Jannasch, H.W.; Wirsen, C.O. Variability of pressure adaptation in deep sea bacteria. Arch. Microbiol. 1984, 139, 281-288. [CrossRef]

40. Talley, L.; Pickard, G.; Emery, W.; Swift, J. (Eds.) Typical Distributions of Water Characteristics. In Descriptive Physical Oceanography; Elsevier Ltd.: Amsterdam, The Netherlands, 2011; pp. 67-110.

41. Dutta, P.K.; Keller, J.; Yuan, Z.G.; Rozendal, R.A.; Rabaey, K. Role of Sulfur during Acetate Oxidation in Biological Anodes. Environ. Sci. Technol. 2009, 43, 3839-3845. [CrossRef] [PubMed]

42. Gong, Y.; Ebrahim, A.; Feist, A.M.; Embree, M.; Zhang, T.; Lovley, D.; Zengler, K. Sulfide-driven microbial electrosynthesis. Environ. Sci. Technol. 2013, 47, 568-573. [CrossRef] [PubMed]

43. Li, S.L.; Nealson, K.H. Enriching distinctive microbial communities from marine sediments via an electrochemical-sulfideoxidizing process on carbon electrodes. Front. Microbiol. 2015, 6, 111. [CrossRef]

44. Rabaey, K.; Clauwaert, P.; Aelterman, P.; Verstraete, W. Tubular microbial fuel cells for efficient electricity generation. Environ. Sci. Technol. 2005, 39, 8077-8082. [CrossRef] [PubMed]

45. McDonough, K.M.; Dzombak, D.A. Microcosm Approach to Study Transport of Polychlorinated Biphenyls in Sediment. J. Environ. Eng. 2006, 132, 689-693. [CrossRef]

46. Scoma, A.; Garrido-Amador, P.; Nielsen, S.D.; Roy, H.; Kjeldsen, K.U. The Polyextremophilic Bacterium Clostridium paradoxum Attains Piezophilic Traits by Modulating Its Energy Metabolism and Cell Membrane Composition. Appl. Environ. Microbiol. 2019, 85, e00802-e008019. [CrossRef]

47. Revsbech, N.P.; Jorgensen, B.B. Microelectrodes-Their use in Microbial Ecology. Adv. Microb. Ecol. 1986, 9, $293-352$.

48. Revsbech, N.P. An Oxygen Microsensor with a Guard Cathode. Limnol. Oceanogr. 1989, 34, 474-478. [CrossRef] 
49. Jeroschewski, P.; Steuckart, C.; Kuhl, M. An amperometric microsensor for the determination of $\mathrm{H}_{2} \mathrm{~S}$ in aquatic environments. Anal. Chem. 1996, 68, 4351-4357. [CrossRef]

50. Marzocchi, U.; Bonaglia, S.; van de Velde, S.; Hall, P.O.J.; Schramm, A.; Risgaard-Petersen, N.; Meysman, F.J.R. Transient bottom water oxygenation creates a niche for cable bacteria in long-term anoxic sediments of the Eastern Gotland Basin. Environ. Microbiol. 2018, 20, 3031-3041. [CrossRef] [PubMed]

51. Li, W.W.; Yu, H.Q. Stimulating sediment bioremediation with benthic microbial fuel cells. Biotechnol. Adv. $2015,33,1-12$. [CrossRef] [PubMed] 